\title{
BASICS OF INTERCULTURAL COMMUNICATION WITH THE ARABIC COMMUNITY
}

\author{
Aldona Maria Piwko ${ }^{7}$
}

\begin{abstract}
Intercultural communication is a mutual communicating of individuals or groups representing different cultures, which are used in a variety of ways to establish mutual relations. The aim of intercultural communication is to know the behavior, customs, ceremonies, and beliefs of the other cultures. Avoiding or a total lack of contacts with representatives of other cultures brings ignorance of the complexity of the social world and its wealth and can cause a culture shock, as well as the conflict of cultures. However, in order to properly carry out this kind of communication, it is necessary to know the basic building blocks for a particular social group, consisting of: history, oral tradition, language, beliefs and customs. It is also important noticing the differences between cultures. Intercultural dialogue naturally creates difficulties, since they meet in the representatives of different cultures. Acceptance of differences leads to developing proper coexistence societies, which is especially important in the current world.
\end{abstract}

Keywords: intercultural communication, Muslim, Islam, culture, Arab.

\section{Introduction}

From the beginning, the world was multicultural; there were many ethnic groups, languages, religions and manners. However, it was only the 20th century that made the people of the world aware all of their diversity. Intensive mixing of the population took place, which was possible due to the development of means of transport and popularization of collective tourism, as well as forced migration. Undoubtedly, the most visible element of multiculturalism of the world is the linguistic diversity which is at the basis of interpersonal communication [Kusio 2011, pp. 16-18].

Communication is one of the main and fundamental human needs, because it is used to transfer information and feelings between people. Communicating is to make the listener feel the same thoughts and feelings that the speaker has. Thus, it can be concluded that interpersonal communication consists of two main aspects: information transfer and relationship formation. Intercultural communication is a mutual communication between people or groups representing different cultures, in which different ways of establishing a mutual relationship are used. The purpose of intercultural communication is to learn about behaviors, customs, ceremonies and beliefs of the other party. 
Avoiding or completely lacking contact with representatives of other cultures brings with it ignorance about the complexity of the social world and its richness, and can be a cause of culture shock as well as conflict of cultures. However, to properly conduct this kind of communication it is necessary to learn the basic elements shaping a given social group, which include: history, oral tradition, language, beliefs and customs. It is also important to notice the differences between cultures. Conducting intercultural dialogue naturally creates difficulties because of different cultural backgrounds met.. Acceptance of differences favors the development of proper coexistence of societies, which is especially important in the present world.

The inspiration for this article was the development of the concept of dimensions of national cultures by Geert Hofstede [2010] and Edward Hall's publication Ukryty wymiar [1978]. In the analysis of ways of communication with the Arab community, the publications of Urszula Kusio [2011], Monika Czerwonka [2015] and an interesting approach to intercultural communication by Michał Wilczewski and Anne-Marie Søderberg [2017], extended by aspects of cultural theory, and a book by Marek Szopski [2005] will also be helpful Cultural diversity in individual countries will increase due to changes in the world's societies, at least in connection with migration of various etiologies. Since 1991, Robert House of the Wharton School of the University of Pennsylvania conducts his multi-stage cultural research, developed among 62 societies of the world on five continents. The project is entitled GLOBE (The Global Leadership and Organizational Behavior Effectiveness) and focuses on taking cultural aspects into account in individual regions of the world. The study groups of world regions can be divided into ten Country Cluster, and Islam is present in three [Gupta and Hanges, 2004, pp. 178-218]. To date, researchers have shown that proper solving of cultural problems by understanding differences is particularly important for proper development and economic activity, but also for organization and communication in multicultural environments [Komor, 2013, p. 115-116].

\section{Methods}

Intercultural communication has many dimensions and can be analyzed in many ways. This article aims to analyze ways of communication, indication of barriers and obstacles in the dialogue conducted by Euro-American societies with representatives of the broadly understood Arab-Muslim culture. Research on intercultural communication usually focuses on ethnic and national differences, because these appear to be the most vivid in the meeting of representatives of different cultures. This article also adopts this principle because the goal is to point out the differences in a seemingly simple activity of conversation. The primary goal of the research is to clarify contacts between people from different cultures. In their course, communication meanings are created, built on various foundations: cultural experiences, perception of the world, and different behaviors in specific contexts [Kwiatkowska, 2014, pp. 10-11]. The article is the theoretical identification of the dimensions of Muslim culture and its representatives in relations with people from other cultural and religious circles. An important element of the article is the religious dimension, characteristic of Islam. The most common problems and misunderstandings arising in relationships with Muslims are those arising from ethical principles deeply rooted in religion and culture. In the Arab world, there is no division between the sacred and the profane. All rules of coexistence must be in accordance with religion and morality. The article refers only to intercultural relations with the followers of Islam and connections with moral norms imposed by this religion. At the same time, it should be clearly emphasized that not all Arabs are Muslims.

In the process of intercultural communication an important element is the identity of the interlocutors. Identity is an individual representation of who I am, and at the same time is a dynamic process, subjected to constant changes and transformations, within an unspecified time frame. The development along with the transformation of identity depends on the cultural environment and the social environment in which the person 
lives. The identity features of the interlocutors appear during the communication process and depend on the participants of the dialogue and its subject.

The tragic events in Europe, perpetrators of which were people associated with Muslim terrorism, meant that in a situation of conversation with representatives of the Middle East, the most important element shaping identity is their cultural and religious affiliation, determining the perception of people, and often the manner of conducting the conversation. There are three categories of identity: ethnic and racial, and religious. Racial identity shows specific physical features that shape a person's social and cultural image. Ethnic identity, on the other hand, does not give special importance to external features, because identification with a given cultural group that combines language, customs, clothing, manner and lifestyle is important. Identity built on cultural elements is often a source of conflict and violence, but it can also be a force in unity, which will allow you to survive hardships. Finally, a religious identity that is extremely important to many people. At the same time, belonging to a specific religious community can be a source of intercultural conflicts. The problem in communication is to distinguish between religious and ethnic identity, because simplifications are often used: a Pole is a Catholic and an Arab is a Muslim [Szopski, 2005, pp. 28-36].

Each conversation takes place according to the following scheme: sender - channel - recipient. In the dialogue of people from different cultures, it is difficult to send and receive messages because both parties use different cultural codes necessary to encode and decode information. It is these differences that cause misunderstandings between the participants of the conversation, and consequently irritation and negative feelings of the interlocutors, along with accusations of bad education. The message directed to a representative of another cultural circle must be clearly corrupted and precisely conveyed; otherwise it will be misinterpreted by the recipient and, as a consequence, will be incomprehensible. Using the same language in intercultural communication can also generate significant problems in communication. This is because of the cultural context of the interlocutors. The dissonance will be present in the conversation between the American and the Englishman in English, as well as between a Pole and an Arab who speak Arabic or Polish.

Arabic from the beginning of the spread of Islam played an important role in the integration of societies initially Arab Peninsula, and with the expansion of religion became the official language of the Muslim Empire. Of course, using a specific language code is an important element of interpersonal communication, but it is not the most important. Interpersonal communication, regardless of culture, is influenced by various factors, which are classified as follows: words $7 \%$, voice tone $38 \%$ and facial expressions and gestures 55\% [Lapakko, 2007, pp. 7-9]. The low meaning of words in mutual communication is emphasized even more in the case of various restrictions present among professional, social and cultural groups. It should also be remembered that words do not always and fully express what the speaker wants to convey. So the question arises: how to speak properly to be understood?

In intercultural communication, to which representatives of the Euro-American tradition, i.e. Latin and Middle Eastern societies, are parties, there are several barriers to the correct exchange of information. Undoubtedly, the main obstacle is the high degree of difficulty of the Arabic language characterized by a multitude of dialects, which significantly affects the in-depth knowledge of this language code. The second communication barrier is the expression of Arabic-speaking speakers. A characteristic feature of the Arab talks is the raised voice, as well as frequent repetition of the same information, along with calling God to witness, which for a Latin listener can mean a quarrel. In addition, the people of the Middle East lively gesticulate to strengthen their speech. In the Arabic environment it is natural to shout at the interlocutor and interrupt the speech. However, it should be clearly emphasized that such behavior occurs in people of similar ages and social status, as well as in social relationships. Such behavior is unacceptable 
to older people or people above the social hierarchy who deserve respect. Such behavior is also not found in professional relations. As already shown in other parts of this publication, Middle Eastern society is not homogeneous. This diversity is also evident in the area of communication. Bedouins and the inhabitants of the Arabian Peninsula are less noisy than the rest of the population of the region. It is also worth noting the greater distance in interpersonal relations present in the Gulf States [Nydell, 2001, pp. 114-115].

\section{Analysis}

\section{Dimensions of national culture}

Different value systems present in many cultures of the world are of significant importance in shaping the behavior of representatives of these cultures. On this basis, Geert Hofstede ${ }^{2}$ developed and described four dimensions of the values of national cultures, which are: power distance (strength of social hierarchy); individualism-collectivism; masculinity-femininity (task-orientation versus person-orientation) and uncertainty avoidance.

\subsection{Power distance}

The distance of power also referred to as hierarchy, describes the ability to subordinate people to senior positions, both in everyday life, social and professional life. The distance of power shows the attitude to the problem of social inequality and unequal distribution of power. The population of countries with high hierarchy accepts the legitimacy of power diversity, assuming the "infallibility" of power, while the young generation is brought up in obedience and respect for elders. Arab countries are characterized by a large distance of power. This acceptance is especially evident in the exercise of state functions, as the community usually supports authoritarian leadership. Whereas cultures with a low power distance are characterized by democracy and the desire to overcome social differences [Szopski, 2005, pp. 62-63].

\subsection{Individualism and collectivism}

Individualism and collectivism describes the importance of a person's good for the community or for the good of the community. There are many more collectivist societies in the world that place the group in the center of attention to maintain harmony. In these types of cultures, the value of an individual is determined by belonging to a group that supports individuals but expects loyalty. Collectivism is also characterized by the type of publicly expressed opinions that should be socially accepted and in line with applicable values. Inhabitants of Arab countries belong to collectivist cultures, which is also sanctioned in Muslim law. The Maliki school of Islam law applies the istislah principle of making sentences favorable to the whole community, not just the individual. The essence of human earthly life is to remain in a group, defined as ummah, and to care for the well-being of all its members. Muslim collectivism is also evident in the way they live every day, such as the crowds at the bazaars [Hall, 1978, p. 207]. Individuality, on the other hand, emphasizes the value and good of a particular person, respecting their otherness, as well as their own views, which may be in opposition to accepted norms [Boski, 2009, pp. 96-101].

\subsection{Masculinity and femininity}

Femininity and masculinity of culture is a definition of the social roles of particular sexes. Men's cultures are characterized by typical male behaviors and attitudes, i.e. as-

\footnotetext{
$2 \quad$ Geert Hofstede (born 1928) Dutch social psychologist, recognized researcher of the relationship between organizational culture and national culture. In the 1980s, he conducted research among IBM group employees employed in many countries, based on which he found that thinking feeling, behavior patterns distinguish members of individual groups from each other, creating an organizational culture and it is characteristic of representatives of a given nation.
} 
sertiveness, authority, ambition, tendency to compete, striving to achieve professional and material success, as well as the ability to show strength, courage as well as physical and mental advantage. And guardianship, service to children and those in needs is perceived as a female trait. In contrast, women in a biological sense should be obedient, subordinate and deprived of self-confidence. This division of social functions applies in the Islamic world. That is why Arabs often find it difficult to accept a woman as an equal partner in the conversation. The older generation of Arab men, with difficulty, also accepts women practicing the profession, seen as typically male, e.g. a female soldier. Also, a woman's leadership over men is a challenge often not acceptable to men. The problem of women exercising supreme function over men is most often manifested in relations between a woman and an officer: Border Guard, Police, and Prison Service versus male-Muslim [Urbanek, 2018, p. 113].

In turn, women's cultures characterize the social functions of women and men in a biological sense, interchangeably, so both women and men can, and in highly developed societies should take the same actions. There are no obstacles to the woman being the president of the state or the president of an international corporation. Similarly, there are no contraindications for a man to look after children and clean at home. Thus, both sexes can be active and assertive, as well as protective and passive. In women's cultures there is no division between brave men and shy women. An example is the prison way of organizing life. In the biologically male community, there is a division into male and female roles in which the weaker prisoners are subordinated to the stronger. However, it should be remembered that women's and men's cultures should not be perceived in a biological sense, because male functions can be performed by women and vice versa. Social expectations are important [Szopski, 2005, pp. 60-62].

\subsection{Uncertainty avoidance}

Uncertainty avoidance determines the ability of a community to accept unpredictable situations, and thus to what extent an unplanned situation creates a sense of danger for a person and how big the challenge is. A culture with a high degree of uncertainty avoidance, and Poland is in this group, beware of unforeseen and unplanned activities, and avoid any improvisation. Unknown and dynamic changes are seen as a threat. Uncertainty avoidance has apparently appeared among Poles in a situation of increased migration movement in Europe and terrorist acts. These events intensified the reluctance to help those in need. Arab countries also have a high uncertainty avoidance rate. In contrast, in a society with a low uncertainty avoidance rate, new events are received with interest. The number of regulations is also limited to allow for wide, unfettered operation [Czerwonka, 2015, pp. 288-290].

\section{Important cultural differences}

There are many barriers to intercultural communication, resulting from the diverse hierarchy of values used in communities, as well as the difference in the way of life of the world's population. On this basis, four main criteria for cultural differences can be distinguished, in each group opposition behaviors were distinguished, according to which the researchers classified the world's population. According to this division, the people of the Middle East belong to the following cultures: high context, pro partner, ceremonial and polychronic [Gasteland, 2000, p. 26].

\subsection{High context culture}

Edward T. Hall ${ }^{3}$ divided cultures into high context and low context. The context of culture is a factor that additionally hinders the communication of representatives of the

Edward Hall (1914-2009) American ethnologist and anthropologist. In the 1930s, he lived among Indian tribes, while in the 1940s he conducted fieldwork in the Middle East. He is the author of books on intercultural communication. 
Latin world with Middle Eastern society. According to these characteristics, Arabs belong to high-context cultures, so communication is carried out indirectly. The information provided is ambiguous, not entirely clearly and precisely defined. A special place in the dialogue is occupied by non-verbal communication, especially the circumstances, gestures and facial expressions. For the Arabs, the way of talking is also important, i.e. looking at the interlocutor. In communication, it is important to maintain eye contact, but you also should not stare intensively at the interlocutor, and also do not wander around the walls, because such behavior means disregarding the interlocutor. Probably for this reason, it is rare for Arabs to have a conversation during a walk. Looking ahead and talking at the same time is seen as a lack of due respect for the interlocutor. Also, sitting back to someone is considered a lack of upbringing. Participants of the conversation have the same knowledge, views and adhere to the same principles, so many elements do not have to be spoken, and it is known what is being said. Important in the conversation is the formal page of the meeting, which includes the position of the interlocutors, their reputation, age and social status. The listener participating in the debate should have knowledge of the topic discussed, because it is tactless to ask for clarification. The form of speech remains very polite, despite frequent interruptions and interruptions to digressions. For representatives of low-context culture, i.e. mainly Europeans and Americans, such a conversation seems to be pointless, not leading to agreement.

However, among low-context cultures, the main communication tool is the word, non-verbal elements such as tone of voice, facial expressions and gestures remain in the background. The statement is clear, literal, and should be concise. The speaker should have high speaking skills and provide detailed information. However, the listener should be focused on the transmitted message, and in case of ambiguity ask for clarifications. Participants of the debate do not attach particular importance to the status of interlocutors; they also do not avoid difficult and uncomfortable topics [Zięba, 2008, p. 252].

\subsection{Pro-partner culture}

Arabs are representatives of the pro-partner culture, which strives to maintain positive relationships with the conversation partner; often this relationship is more important than achieving final success. In a special way this feature is visible in business relations. For the representatives of this cultural circle, a personal bond is important, because partnership is not limited to professional issues, it also includes personal life. Establishing a partner relationship generates communication problems. This is due to the careful selection of words so as not to offend the other party. You can rarely hear a strong "no" or a definite "yes". Lack of ambiguity can irritate a transactional oriented European and shape the distorted image of an interlocutor as undecided. Partnership communication emphasizes feelings and own needs as well as desires along with the expectations of the partner in the conversation. However, in dialogue he does not impose his own views, he does not judge, showing great tolerance, expecting understanding for his own attitude. In relations with a representative of the Arab world, it is important to get to know each other's partners; this is how trust is built. Therefore, do not rush and shorten the topics of conversations, because such behavior is perceived as rude [Zaharna, 1995]. On the other hand, Europeans largely belong to the culture of transactional activity, and thus it emphasizes and emphasizes the importance of the needs of only one party in communication, which can consist of striving to achieve their own goals, or total resignation. This attitude is characterized by not allowing the opponent to speak in the discussion, and often also by ignoring the interlocutor by imposing his own opinion. A non-partner style of communication may also take the form of subordinating one's views to the participants of the dialogue [Witaszek, 2007, p 107].

\subsection{Ceremonial culture}

Middle Eastern communities, like European countries, belong to ceremonial cultures, so special importance is attached to social hierarchy, the use of official titles, and 
showing due respect for people with high social status. This is emphasized in direct relations during communication, through the use of phrases Mr., and also in appropriate clothing. Other factors, including gender and age, are important for ceremonial cultures. In the Arab world, especially in the Gulf region, women rarely achieve high professional status, and thus men from this geographical area have difficulties in accepting women in high official or business positions. Arabs belong to cultures of significant importance in the hierarchy, therefore greeting and conversations should be started with the oldest person in the company. The positive image of a partner in cooperation can be strengthened using customary welcome formulas used in the Middle East. Undoubtedly, the most popular greeting is as-salamu alajkum, meaning peace with you, to which the answer is wa-alajkum as-salam, used regardless of the circumstances of the meeting [Khiadyer, 2012, p. 194]. On the other hand, representatives of non-ceremonial cultures do not pay particular attention to the divisions resulting from social status, showing tolerance for differences [Olejniczak, 2014, p. 121].

\subsection{Polychronic culture}

Time perspective is an important element in shaping relationships between people representing different cultural backgrounds. The perception of time and the punctuality associated with it mean that monochronic and polychronic cultures have been distinguished. Representatives of monochronic cultures attach great importance to punctuality, adherence to deadlines and established schedules. It is common to set action plans and use schedules to precisely plan time, thereby improving performance. In contrast, Arabs belong to polychronic cultures for which interpersonal relations are more important than punctuality. In the Middle East, time comes from the past, continues in the present and flows towards the future. That is why meetings in the Arab world do not have a fixed time frame, either beginning or ending. Arabs are very flexible people for whom a set plan is not necessary and obliging. Being late is not received negatively. However, it is very rude to leave the meeting or end the conversation before reaching satisfactory conclusions. Similarly, looking at a watch during a meeting is perceived negatively. In Arab countries, setting deadlines in the future is often seen as an attempt to predict the future, and that in Islam is a sin. A relaxed, Arab approach to the issue of time is often perceived by Europeans as rude, frivolous, and even a sign of laziness [Nydell, 2001, p. 74].

\section{Conclusions}

To sum up, the lives of Arab inhabitants of the Middle East are regulated by religion, which is why many elements contained in Islam are reflected in everyday life. For this reason, Arabs are characterized by a large distance of power, and collectivism is an important factor for the good of society. Middle Eastern countries belong to male cultures, with a clear division of functions of men and women in the community. Finally, Arabs belong to a culture with a high uncertainty avoidance factor, which is why all decisions are made gradually, and trust in the interlocutor is particularly important. All coercion and pressure will be seen as a danger. At the same time, the inhabitants of the Middle East belong to a high context, but also pro-partner culture. Arabs attach great importance to the ceremonial, expressed in emphasizing the hierarchy, status and respect of the conversation partners. In addition, they represent polychronic culture.

\section{References}

BOSKI P. (2009), Kulturowe ramy zachowań społecznych, Warszawa, Wydawnictwo Naukowe PWN.

CZERWONKA M. (2015), Charakterystyka wskaźników modelu kulturowego Hofstede, [in:] 0 nowy ład finansowy w Polsce. Rekomendacje dla animatorów życia gospodarczego, (ed.) J. Ostaszewski, Warszawa, Wydawnictwo SGH, pp. 281-292.

GESTELAND R. (2000), Różnice kulturowe a zachowania w biznesie, Warszawa, Wydawnictwo Naukowe PWN. 
GUPTA V. AND HANGES P. (2004), Regional and Climate Clustering of Societal Cultures, [in:] Culture, Leadership, and Organizations: The GLOBE Study of 62 Societies, (ed.) R. House, P. Hanges, Sage, Thousand Oaks, pp. 178-218.

HALL E. (1978), Ukryty wymiar, Warszawa, Państwowy Instytut Wydawniczy.

HOFSTEDE G. AND G. J. HOFSTEDE (2010), Cultures and Organizations. Software of the mind. Intercultural Cooperation and its Importance or Survival, New York, McGraw Hill.

KHIADYER E. (2012), Arabski świat, Warszawa, Prószyński Media.

KOMOR M. (2013), Charakterystyka Country Cluster według wymiarów kultury GLOBE, „Organizacja i Kierowanie" no 2 (155), pp. 99-119.

KUSIO U. (2011), Dialog w komunikacji międzykulturowej. Ideały a rzeczywistość, Lublin, Wydawnictwo Naukowe UMCS.

KWIATKOWSKA A. (2014), Problemy metodologiczne w badaniach międzykulturowych i kulturowych, „Psychologia Społeczna" no 9 (28), pp. 8-27.

LAPAKKO D. (2007), Communication is 93\% Nonverbal: An Urban Legend Proliferates, "Communication and Theater Association of Minnesota Journal", vol. 34, pp. 7-19.

NYDELL M. (2001), Zrozumieć Arabów, Warszawa, Studio EMKA.

OLEJNICZAK A. (2014), Wpływ różnic kulturowych na rozwój organizacji, „Studia i Prace Wydziału Nauk Ekonomicznych i Zarządzania", no 37, pp. 117-125.

SZOPSKI M. (2005), Komunikowanie międzykulturowe, Warszawa, Wydawnictwa Szkolne i Pedagogiczne.

URBANEK A. (2018), Kształtowanie się opinii personelu więziennego wobec skazanych muzułmanów o odmiennych potrzebach kulturowych, „Muliticultural Studies” no 1, pp. 101-118.

WILCZEWSKI M. AND A.M. SøDERBERG (2017), Badania nad komunikacją międzykulturową: dotychczasowe paradygmaty i perspektywy badawcze, „Zeszyty Prasoznawcze” no 3 (231), pp. 540-566.

WITASZEK Z. (2007), Kulturowe uwarunkowania negocjacji oraz zasady ich prowadzenia, „Zeszyty Naukowe Akademii Marynarki Wojennej", no 1 (168), pp. 101-119.

ZAHARNA R.S. (1995), Understanding Cultural Preferences of Arab Communication Patterns, „Public Rela-tions Review" no 21 (3), pp. 241-255.

ZIĘBA A. (2008), Język a kultura. Komunikacja werbalna w wybranych polskich, brytyjskich i amerykańskich programach telewizyjnych, „Investigationes Linguisticae”, vol. 14, pp. 250-263. 